\title{
Analysis of Horse Myostatin Gene and Identification of Single Nucleotide Polymorphisms in Breeds of Different Morphological Types
}

\author{
Stefania Dall'Olio, ${ }^{1}$ Luca Fontanesi, ${ }^{1}$ Leonardo Nanni Costa, ${ }^{1}$ Marco Tassinari, ${ }^{2}$ \\ Laura Minieri, ${ }^{3}$ and Adalberto Falaschini ${ }^{2}$ \\ ${ }^{1}$ DIPROVAL, Sezione di Allevamenti Zootecnici, Faculty of Agriculture, University of Bologna, 42123 Reggio Emilia, Italy \\ ${ }^{2}$ DIMORFIPA, Sezione di Zootecnia, Faculty of Veterinary Medicine, University of Bologna, 40064 Ozzano Emilia, Italy \\ ${ }^{3}$ Department of Human and General Physiology, Faculty of Medicine, University of Bologna, 40127 Bologna, Italy
}

Correspondence should be addressed to Stefania Dall'Olio, stefania.dallolio@unibo.it

Received 3 August 2009; Revised 20 February 2010; Accepted 27 April 2010

Academic Editor: Peter Dovc

Copyright (C) 2010 Stefania Dall'Olio et al. This is an open access article distributed under the Creative Commons Attribution License, which permits unrestricted use, distribution, and reproduction in any medium, provided the original work is properly cited.

\begin{abstract}
Myostatin (MSTN) is a negative modulator of muscle mass. We characterized the horse (Equus caballus) MSTN gene and identified and analysed single nucleotide polymorphisms (SNPs) in breeds of different morphological types. Sequencing of coding, untranslated, intronic, and regulatory regions of MSTN gene in 12 horses from 10 breeds revealed seven SNPs: two in the promoter, four in intron 1, and one in intron 2. The SNPs of the promoter (GQ183900:g.26T >C and GQ183900:g.156T >C, the latter located within a conserved TATA-box like motif) were screened in 396 horses from 16 breeds. The g.26C and the g.156C alleles presented higher frequency in heavy (brachymorphic type) than in light breeds (dolichomorphic type such as Italian Trotter breed). The significant difference of allele frequencies for the SNPs at the promoter and analysis of molecular variance (AMOVA) on haplotypes indicates that these polymorphisms could be associated with variability of morphology traits in horse breeds.
\end{abstract}

\section{Introduction}

Myostatin, encoded by the MSTN gene (previously referred to as GDF8), is a member of the transforming growth factor $\beta$ superfamily that normally acts to limit skeletal muscle mass by regulating both the number and growth of muscle fibres $[1,2]$. MSTN is synthesized as precursor and upon proteolytic processing gives an N-terminal latencyassociated peptide, termed myostatin propeptide or LAPfragment, and a smaller mature peptide at the C-terminus [3]. The MSTN gene, composed of three exons and two introns, has been characterized in rodents [1], humans [4], and several livestock species [3,5-8]. Natural mutations that decrease the amounts of myostatin and/or inhibit its function have been identified in a human subject [9] and in several cattle [2, 3, 10-13], sheep [14-16], and dog [17] breeds. In Belgian Blue, Piedmontese, Marchigiana, and other cattle breeds, loss-of-function mutations within the coding sequence of the MSTN gene determine increased skeletal muscle mass, relevant in shoulders and thighs, and the produced phenotype is known as "double-muscling" $[2,3,10-13,18]$. These polymorphisms have, in several cases, effects on growth, reproductive, performances, and carcass quality traits $[3,18,19]$. In the Whippet dog breed a mutation in the third exon determining a premature stop codon causes an increased muscle mass phenotype in homozygous state and enhanced racing performance in heterozygous dogs [17]. In two Norwegian sheep breeds, two different mutations in the MSTN coding region are associated with carcass conformation and fatness $[15,16]$. In addition, in other sheep and in pigs, mutations identified in non coding regulatory regions affect the level of MSTN gene expression and/or are associated with growth, muscle mass, and other carcass traits $[8,14,20,21]$. 


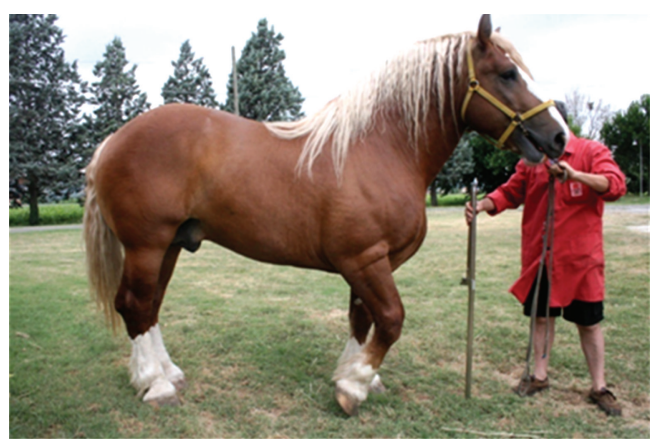

(a)

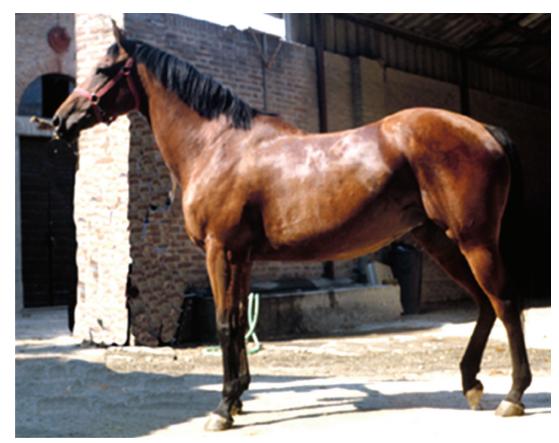

(b)

FIGURE 1: Horses of extreme and opposite morphological types:(a) Rapid Heavy Draft (brachymorphic type or heavy) and (b) Italian Trotter (dolichomorphic type or light).

In horse (Equus caballus), only few studies examined the MSTN gene so far. Hosoyama et al. [22] isolated and sequenced an MSTN cDNA from a Thoroughbred horse and Caetano et al. [23] mapped this gene to equine chromosome 18. Mutations in the equine MSTN gene have been identified only recently in Thoroughbred breed [24].

Different horse breeds present a variety of morphological phenotypes that have been used to group breeds into a few classes. However, no system provides a robust classification in which each breed could have an unequivocal assignment. Based on size traits and build, horse breeds are categorized in draught (or heavy), light, and pony (or animals that mature at less than $148 \mathrm{~cm}$ high, usually used as riding school and children's mounts) [25]. Considering skeletal structure, proportions, zoometrical indices, length, and volume of muscling, that, in turn, reflect the selective goals and uses of the horse breeds, they are categorized in brachymorphic, mesomorphic, dolichomorphic, and intermediate types (such as meso-dolichomorphic) [26]. Brachymorphic horses (corresponding to draught horses), traditionally referred to as cold-blooded horses in relation to their quiet and calm temperament, are tall in stature, heavy boned, and extremely muscular with short and thick muscles and slow twitch oxidative fibers for slow contraction. They most likely develop strength and power, and their conformation is well suited for pulling carriage, draught power and meat production. Dolichomorphic horses (corresponding to light horses) are characterized by longer bodies and long and thin muscles mainly constituted by fast twitch glycolytic fibers. They are selected for sport purposes, fast running, and high speeds. Examples of Italian breeds representative of these two extreme phenotypes are reported in Figure 1. Mesomorphic type is characterized by a lighter physical structure than brachymorphic but still powerful and compact with massive muscling. This group also includes some breeds with drafttype qualities and classified as ponies based on their withers height (such as Bardigiano and Haflinger breeds). The mesomorphic horses are usually used for pleasure and riding. In addition, several breeds (like local breeds with influence of Oriental, Thoroughbred, and Iberian halfbreed and descendents) have characteristics of both mesomorphic and dolichomorphic types (referred to as meso-dolichomorphic) [26].

For the important pleiotropic effects of the MSNT gene, including its role on muscle mass development, polymorphisms in this gene could contribute to explain the morphological variability among horse breeds. Here we sequenced the MSTN gene, including regulatory regions, in several horse breeds and identified a few polymorphisms that were used to evaluate their potential association with different morphological types.

\section{Materials and Methods}

2.1. Animals and Horse Breeds Classification Based on Different Morphological Types. A total of 396 minimal related horses belonging to 16 breeds were sampled in different farms or stables. Details of the horse breeds involved in the analysis are given in Table 1.

These horse breeds were classified as brachymorphic (B), mesomorphic, (M), meso-dolichomorphic (M-D), and dolichomorphic (D) (Table 1) as indicated in the homepage of their own Breed National Associations based on linear measures (height at withers, chest girth, and cannon circumference), structure and anamorphosis index $(\mathrm{AI}=$ (chest girth $)^{2} * 100$ /height at wither), and based on bibliographic data [27-30].

All horses were registered in the Stud Books or in the Italian Anagraphic Register constituted for local ethnic groups (Noric, Salernitano, Tolfetano, and Ventasso). The Lipizzan samples (Lipizzan Italian Stud, Monterotondo, Italy) included all six classical stallion lines: Conversano, Favory, Maestoso, Neapolitano, Pluto, and Siglavy.

2.2. PCR and Sequencing. Genomic DNA was extracted from hair roots following standard procedures. Ten primer pairs (Table 2) that amplify different MSTN regions were designed using Primer 3 (http://frodo.wi.mit.edu/primer3/input.htm) software. PCR reactions were performed in a final volume of $20 \mu \mathrm{L}$ containing $10-80 \mathrm{ng}$ of equine genomic DNA, $250 \mathrm{mM}$ of each dNTP, 10 pmol of each primer, $1 \mathrm{U}$ of EuroTaq DNA 
TABLE 1: Numbers, types, origin, uses, and morphological information of the analysed horse breeds* .

\begin{tabular}{|c|c|c|c|c|}
\hline International breed name (Home page of Breed National Associations) & Types ${ }^{\S}$ & $\begin{array}{l}\text { Number of } \\
\text { horses }\end{array}$ & $\begin{array}{l}\text { Origin of the } \\
\text { samples }\end{array}$ & $\begin{array}{l}\text { Uses (adult animals, } \\
\text { males/females: withers } \\
\text { height, } \mathrm{cm} \text {; live weight, } \mathrm{kg} \text { ) }\end{array}$ \\
\hline Rapid Heavy Draft (http://www.anacaitpr.it/) & B & 81 & $\begin{array}{l}\text { North East of } \\
\text { Italy }\end{array}$ & $\begin{array}{l}\text { Meat, draught power } \\
(160 / 155 \mathrm{~cm} ; 700 / 570 \mathrm{~kg})\end{array}$ \\
\hline Noric or Pinzgauer (http://www.aia.it/tecnico/equini/a_norico.htm) & B & 26 & $\begin{array}{l}\text { Alps, Northern } \\
\text { Italy }\end{array}$ & $\begin{array}{l}\text { Draught power, driving, } \\
\text { carriage, dressage, meat } \\
(155 / 153 \mathrm{~cm} ; 700 / 650 \mathrm{~kg})\end{array}$ \\
\hline Bardigiano (http://www.bardigiano.it/) & M & 34 & $\begin{array}{l}\text { Emilia } \\
\text { Romagna } \\
\text { region, } \\
\text { Northern Italy }\end{array}$ & $\begin{array}{l}\text { Meat, agricultural work, } \\
\text { hobby }(143 / 142 \mathrm{~cm} \text {; } \\
530 / 480 \mathrm{~kg})\end{array}$ \\
\hline Haflinger or Avelignese (http://www.haflinger.it/) & M & 31 & Northern Italy & $\begin{array}{l}\text { Hobby, meat, draught } \\
\text { power }(142 / 140 \mathrm{~cm} \text {; } \\
450 / 450 \mathrm{~kg})\end{array}$ \\
\hline $\begin{array}{l}\text { Lipizzan or Lipizzaner } \\
\text { (http://www.aia.it/tecnico/equini/a_lipizzano.htm) }\end{array}$ & M & 12 & $\begin{array}{l}\text { Rome, Central } \\
\text { Italy }\end{array}$ & $\begin{array}{l}\text { Dressage, riding, carriage } \\
(164 / 150 \mathrm{~cm} ; 550 / 480 \mathrm{~kg})\end{array}$ \\
\hline $\begin{array}{l}\text { Murgese } \\
\text { (http://www.aia.it/tecnico/equini/download/DM\%20MURGESE.pdf) }\end{array}$ & M & 12 & $\begin{array}{l}\text { Apulia region, } \\
\text { Southern Italy }\end{array}$ & $\begin{array}{l}\text { Riding, equestrian tourism, } \\
\text { draught power } \\
(164 / 162 \mathrm{~cm} ; 550 / 480 \mathrm{~kg})\end{array}$ \\
\hline Tolfetano (http://www.aia.it/tecnico/equini/a_tolfetan.htm) & M & 7 & $\begin{array}{l}\text { Latium region, } \\
\text { Central Italy }\end{array}$ & Riding $(160 / 150 \mathrm{~cm})$ \\
\hline $\begin{array}{l}\text { Uruguayan Creole or Criollo } \\
\text { (http://www.caballoscriollos.com.uy/homepage_en.php) }\end{array}$ & M & 35 & Uruguay & $\begin{array}{l}\text { Draught power, } \\
\text { government of livestock, } \\
\text { endurance }(144 / 144 \mathrm{~cm} \text {; } \\
420 / 420 \mathrm{~kg})\end{array}$ \\
\hline Italian Saddle (http://www.aia.it/ANACSI/Frame.htm) & M-D & 30 & $\begin{array}{l}\text { Country wide, } \\
\text { Italia }\end{array}$ & $\begin{array}{l}\text { Riding, equestrian tourism, } \\
\text { drift competitions } \\
\text { (jumping, dressage, } \\
\text { complete, endurance) (min } \\
156 \mathrm{~cm} \text { ). }\end{array}$ \\
\hline Maremmano (http://www.anamcavallomaremmano.com) & M-D & 13 & $\begin{array}{l}\text { Tuscany } \\
\text { region, Central } \\
\text { Italy }\end{array}$ & $\begin{array}{l}\text { Riding, equestrian tourism, } \\
\text { draught power, } \\
\text { government of livestock } \\
(165 / 162 \mathrm{~cm} ; 500 / 450 \mathrm{~kg})\end{array}$ \\
\hline Quarter Horse (http://www.aiqh.it) & $\mathrm{M}-\mathrm{D}$ & 15 & $\begin{array}{l}\text { Emilia } \\
\text { Romagna } \\
\text { region, Italy }\end{array}$ & $\begin{array}{l}\text { Riding, equestrian tourism } \\
(160 \mathrm{~cm} ; 550 / 350 \mathrm{~kg})\end{array}$ \\
\hline $\begin{array}{l}\text { Salernitano or Salernitano-Persano } \\
\text { (http://www.agraria.org/equini/salernitano.htm) }\end{array}$ & M-D & 4 & $\begin{array}{l}\text { Campania } \\
\text { region, } \\
\text { Southern Italy }\end{array}$ & $\begin{array}{l}\text { Riding, equestrian tourism } \\
(158 / 150 \mathrm{~cm} ; 500 / 450 \mathrm{~kg})\end{array}$ \\
\hline Spanish Purebred or Andalusian (http://www.aipre.com) & $\mathrm{M}-\mathrm{D}$ & 10 & $\begin{array}{l}\text { Emilia } \\
\text { Romagna } \\
\text { region, Italy }\end{array}$ & $\begin{array}{l}\text { Sport, hobby }(160 / 155 \mathrm{~cm} \text {; } \\
570 \mathrm{~kg})\end{array}$ \\
\hline Ventasso (http://www.aia.it/tecnico/equini/a_ventass.htm) & M-D & 8 & $\begin{array}{l}\text { Emilia- } \\
\text { Romagna } \\
\text { region, } \\
\text { Northern Italy }\end{array}$ & $\begin{array}{l}\text { Equestrian tourism } \\
(164 / 152 \mathrm{~cm})\end{array}$ \\
\hline Italian Trotter (http://www.anact.it/) & $\mathrm{D}$ & 67 & $\begin{array}{l}\text { Country wide, } \\
\text { Italy }\end{array}$ & $\begin{array}{l}\text { Selected for competitive } \\
\text { merit as trotter at short and } \\
\text { medium distances } \\
(160-145 \mathrm{~cm})\end{array}$ \\
\hline Throroughbred (http://www.anacpurosangue.com/) & $\mathrm{D}$ & 11 & $\begin{array}{l}\text { Country wide, } \\
\text { Italy }\end{array}$ & $\begin{array}{l}\text { Racehorses (gallop) and } \\
\text { used for genetic } \\
\text { improvement of Italian } \\
\text { local breeds. }\end{array}$ \\
\hline
\end{tabular}

* Based on information obtained from Horse Breeds National Associations, if available. ${ }^{\S}$ Types: $\mathrm{B}=$ brachimorphic or heavy, $\mathrm{M}=$ mesomorphic, $\mathrm{M}-\mathrm{D}=$ mesodolichomorphic, $\mathrm{D}=$ dolichomorphic or light. 
TABle 2: Primers, PCR conditions, amplified regions, and use of the PCR products.

\begin{tabular}{|c|c|c|c|c|c|}
\hline Primer pair & $\begin{array}{l}\text { F: Forward sequence }\left(5^{\prime}-3^{\prime}\right) \\
\text { R: Reverse sequence }\left(5^{\prime}-3^{\prime}\right)\end{array}$ & $\begin{array}{l}\text { Primer annealing } \\
\text { regions }\end{array}$ & $\begin{array}{l}\text { Amplified region } \\
\text { (bp)* }\end{array}$ & PCR conditions ${ }^{\S}$ & $\begin{array}{l}\text { Use of the PCR } \\
\text { products }\end{array}$ \\
\hline \multirow[t]{2}{*}{$1^{\#}$} & 1F: TCAGGGAAACAAGTTTCTCAAAT & Promoter & $1-484$ & $58 / 1.5 / 45 /$ & Sequencing, \\
\hline & 1R: TGCTCCACAATGAATCTCG & Promoter & $(484)$ & $\mathrm{E}$ & PCR-RFLP \\
\hline \multirow[t]{2}{*}{$2^{\#}$} & 2F: TGAATCAGCTCACCCTTGAC & Promoter & $369-727$ & $62 / 0.8 / 45 /$ & Sequencing \\
\hline & 2R: CCAGCAACAATCAGCATAAA & Exon 1 & $(360)$ & $\mathrm{E}$ & \\
\hline \multirow[t]{2}{*}{$3 \pi$} & 3F TGTGCTGATTCTTGCTGGTC & Exon 1 & $710-947$ & $58 / 1.5 / 45 /$ & Sequencing \\
\hline & 3R: ATCAATCAGTTCCCGGAGTG & Exon 1 & $(238)$ & $\mathrm{E}$ & \\
\hline \multirow[t]{2}{*}{$4^{\pi}$} & 4F: GACCCGTCAAGACTCCTACA & Exon 2 & $2982-3226$ & $58 / 1.0 / 45 /$ & Sequencing \\
\hline & 4F: TGGGAAGGTTACAGCAAGA & Exon 2 & $(245)$ & $\mathrm{E}$ & \\
\hline \multirow[t]{2}{*}{$5^{\natural}$} & 5F: AGGCCAATTACTGCTCTGGA & Exon 3 & $5430-5744$ & $58 / 1.5 / 45 /$ & Sequencing \\
\hline & 5R: ATACTCTAGGCTTATAGCCT & 3'UTR & $(315)$ & $\mathrm{E}$ & \\
\hline \multirow[t]{2}{*}{$6^{\natural}$} & 6F: CACTCCGGGAACTGATTGAT & Exon 1 & $928-3098$ & $58 / 0.8 / 130$ & Sequencing \\
\hline & 6R: CGCCTGGGTTCATGTCAAGT & Exon 2 & $(2171)$ & $/ \mathrm{T}$ & \\
\hline \multirow[t]{2}{*}{$7^{\natural}$} & 7F: AGGCAGGCACATTGCTTAAT & Intron 1 & $1808-2287$ & $58 / 0.8 / 45 /$ & Sequencing \\
\hline & 7R: GAATGTTATATTCAGGCTATCTCAA & Intron 1 & $(480)$ & $\mathrm{E}$ & \\
\hline \multirow[t]{2}{*}{$8^{\natural}$} & 8F: AAATGTGACATAAGCAAATGATTAG & Intron 2 & $5152-5534$ & $62 / 0.8 / 45 /$ & Sequencing \\
\hline & 8R: AGCAGGGGCCTGCTGAACCTCTGGG & Exon 3 & $(383)$ & $\mathrm{E}$ & \\
\hline \multirow[t]{2}{*}{$9^{n}$} & 9F: TGCAAAATTGGCTCAAACAG & Exon 2 & $3135-5361$ & $55 / 0.8 / 130$ & Sequencing \\
\hline & 9R: CAGCATCGAGATTCTGTGGA & Exon 3 & $(2227)$ & $/ \mathrm{T}$ & \\
\hline \multirow[t]{2}{*}{$10^{\natural}$} & 10F: CCCCCAGAAGAGTGTCAAAT & Intron 2 & $3627-4822$ & $60 / 0.8 / 130$ & Sequencing \\
\hline & 10R: TCTTTACTTGGGGAAACTTGGA & Intron 2 & $(1196)$ & $/ \mathrm{T}$ & \\
\hline \multirow[t]{2}{*}{11} & 1F: TCAGGGAAACAAGTTTCTCAAAT & Promoter & $1-204$ & $53 / 1.2 / 35 /$ & PCR-RFLP \\
\hline & 11R: ACTTCCTCAGAAATTAAGATTTAAT & Promoter & (204) & $\mathrm{E}$ & \\
\hline
\end{tabular}

${ }^{*}$ Numbering accoding to GenBank accession number GQ183900. $\S^{\S}$ Annealing temperature $\left({ }^{\circ} \mathrm{C}\right),\left[\mathrm{MgCl}_{2}\right]$, extension time $(\mathrm{s})$, Taq DNA polymerase $(\mathrm{E}=$

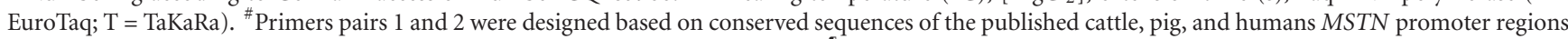
(GenBank accession numbers AJ310751, AJ133580, and AX058992, respectively). " Primer pairs 3-10 were designed based on horse MSTN mRNA sequence (GenBank accession number AB033541).

polymerase (EuroClone Ltd., Paington, Devon, UK), or $1 \mathrm{U}$ of TaKaRa Ex Taq DNA Polymerase (TaKaRa Bio Inc., Shiga, Japan) and $1 \times$ PCR buffer with $\mathrm{MgCl}_{2}$ concentration specific for each primer pair (Table 2). PCR conditions were: an initial step at $95^{\circ} \mathrm{C}$ for 5 minutes, 35 cycles of $95^{\circ} \mathrm{C}$ for $30 \mathrm{~s}$, specific annealing temperature for each primer pair for $30 \mathrm{~s}$, $72^{\circ} \mathrm{C}$ for specific reaction times for different primer pair (Table 2), and a final step at $72^{\circ} \mathrm{C}$ for 9 minutes. Genomic DNA obtained from 12 horses of 10 breeds (1 Bardigiano, 1 Haflinger, 1 Italian Saddle, 2 Italian Trotter, 1 Noric, 2 Rapid Heavy Draft, 1 Salernitano, 2 Throroughbred, and 1 Ventasso) constituted the sequencing panel. PCR fragments obtained from the sequencing panel with primer pairs 110 were purified using the QIAquick PCR Purification Kit (Qiagen, Düsseldorf, Germany) and sequenced on both strands using the BigDye Cycle Sequencing kit v.3.1 (Applied Biosystems, Foster City, CA, USA). Sequencing reactions were electrophoresed in a capillary sequencer (Applied Biosystems).

2.3. Sequence Analysis, Polymorphism Identification, and Genotyping. Sequences were aligned and processed with the help of the BioEdit software v.7.0.5.2. Polymorphisms were identified by visual inspection of the electropherograms and sequences were aligned with ClustalW2 program (http://www.ebi.ac.uk/Tools/clustalw2/index.html) and using BLASTN (http://blast.ncbi.nlm.nih.gov/Blast.cgi). The horse MSTN promoter sequence was analysed in silico for the presence of putative transcription factor binding sites using MatInspector (http://www.genomatix.de/) bioinformatics tool. This region of horse MSTN gene was aligned with that of cattle (AJ310751), goat (AY827576), human (AX058992), mouse (AY204900), pig (AY8641281), and sheep (DQ530260) to identify evolutionary conserved motifs.

PCR-RFLP protocols were designed to genotype two identified SNPs (g.26T $>C$ and g.156T $>C$ ) in the sampled horses. To genotype the g.26T $>$ C SNP, the amplified products of $484 \mathrm{bp}$ obtained with primer pair 1 (Table 2) were digested with RsaI (recognition sequence: GT $\downarrow \mathrm{AC}$ ). Briefly, 5-10 $\mu \mathrm{L}$ of PCR reaction was restricted with $2.5 \mathrm{U}$ of RsaI (Fermentas, Vilnius, Lithuania) at $37^{\circ} \mathrm{C}$ overnight and the resulting fragments (g.26T allele $=484 \mathrm{bp}$; g.26C allele $=437 \mathrm{bp}+47 \mathrm{bp})$ were resolved on $2.0 \%$ agarose gels 


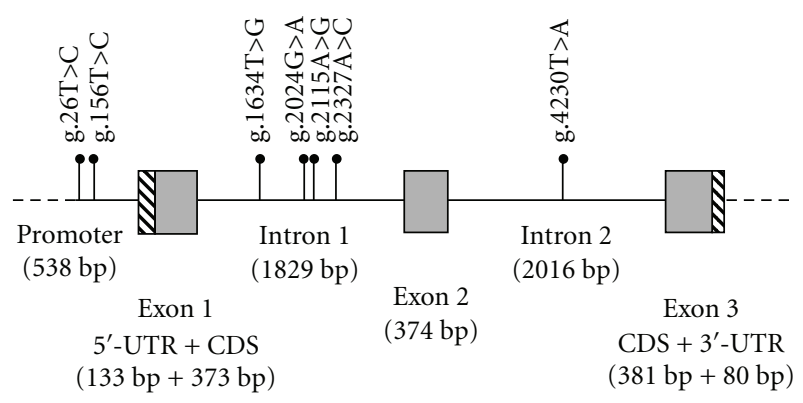

Figure 2: Genomic organization of the horse MSTN gene. Exons are shown as boxes. Solid boxes indicate protein coding regions. Untranslated regions are shown as striped boxes. Size of the sequenced regions of the promoter, exons, and introns is reported. Polymorphisms, indicated according to GenBank accession number GQ183900, are reported on the genomic organization of the gene.

stained with ethidium bromide. The g.156T $>$ C SNP was genotyped amplifying a fragment of $204 \mathrm{bp}$ with primer pair 11 (Table 2) that inserted an artificial restriction site (with a mismatched reverse primer) for SspI (recognition sequence: AAT $\downarrow$ ATT) when allele g.156T occurred. The obtained fragments (g.156T allele $=179 \mathrm{bp}+25 \mathrm{bp}$; g.156C allele $=204 \mathrm{bp}$ ) resulting from digestion of $5-10 \mu \mathrm{L}$ of PCR reaction with $2.5 \mathrm{U}$ of $S s p \mathrm{I}$ (Fermentas) at $37^{\circ} \mathrm{C}$ overnight were electrophoresed in 3.5\% agarose gels and visualized with ethidium bromide.

2.4. Statistical Analysis. Allele and genotype frequencies, observed and expected heterozygosity, and $F_{\text {st }}$ were calculated using PopGene software v. 1.32 [31]. $F_{\text {st }}$ is a measure of population differentiation based on genotypic data. Allele frequencies among the four groups ( $B, M, M-D$, and D) were compared using Fisher's exact test. The haplotypes of the two promoter SNPs were reconstructed using PHASE program v. 2.0 [32]. ARLEQUIN software v. 3.1 (http://cmpg.unibe.ch/software/arlequin3) was used for the analysis of molecular variance (AMOVA) testing the effect of the morphological types in population differentiation with a model including types (four levels: B, M, M-D and $\mathrm{D}$; and two levels: $\mathrm{B}+\mathrm{M}$ and $\mathrm{M}-\mathrm{D}+\mathrm{D})$, types/breeds, individuals/breeds, and individuals.

\section{Results and Discussion}

3.1. Horse MSTN Genomic Structure and Sequence Analysis. Sequenced fragments of the horse MSTN gene were assembled into one sequence of $5724 \mathrm{bp}$ (submitted to GenBank under accession number GQ183900) that resulted 100\% identical with that that was, in the meantime, annotated in the EquCab2 horse genome assembly derived from a Thoroughbred horse (http://www.ensembl.org/Equus_caballus/ Search/, Ensembl release 52-Dec 2009). Our sequence contained $671 \mathrm{bp}$ upstream from the ATG start codon, $538 \mathrm{bp}$ of the promoter, and the entire $5^{\prime}$-untranslated region (UTR) of $133 \mathrm{bp}$, the three exons (except $33 \mathrm{bp}$ of exon 1), the two intervening introns, and $80 \mathrm{bp}$ of the $3^{\prime}$-UTR (Figure 2). The transcription start site of the first exon was deduced from human and bovine MSTN exon 1 sequences $[4,6]$. The coding regions of exons 1,2 , and 3 of the horse MSTN gene contained 373, 374, and $381 \mathrm{bp}$, respectively. Introns 1 and 2 included $1829 \mathrm{bp}$ and $2016 \mathrm{bp}$, respectively, almost the same length reported in cattle (1840 bp and $2033 \mathrm{bp}$, respectively) and pig (1809 bp and $1980 \mathrm{bp}$, respectively) [6, 8]. Intron 1 is a type 1 intron as it interrupts a codon between the first and second exon whereas intron 2 is a type 0 intron as it divides the coding sequence between two codons as in other species $[6,8]$. The analysed proximal promoter region and the $5^{\prime}-$ UTR of the horse MSTN exhibited a degree of identity with the corresponding regions of other species ranging from $77 \%$ (mouse) to $90 \%$ (pig). Putative consensus DNA sequences known as transcription factor binding sites, DNA-binding motifs, or cis-regulatory elements were identified in the positive strand of horse promoter (Figure 3 ). Considering the general transcription factors, three different putative TATA boxes (TATA-1, TATA-2, and TATA-3) and one CCAAT box were detected. Among muscle-specific transcription factors, four E-boxes (named E1, E2, E3, and E4 boxes, Figure 3), one putative site for myocyte specific enhancer factor 2 (MEF2 or MEB1) and consensus sequences for FoxO and SMAD binding sites (CAAAATA and CAGACA, respectively) family sequences were identified. The alignment of MSTN promoter sequences across different species (horse, cattle, goat, human, mouse, pig, and sheep) revealed that these DNA-binding motives, particularly close to the TATA-1 surrounding sequence, were highly conserved across species. In particular, TATA-1 was conserved in all examined species except mouse, the second TATA sequence (TATA-2) was conserved across all seven species, and TATA-3 was conserved in all species except pig and mouse. The MEF2 and E-boxes were conserved in all the considered mammals except in human and mouse for E-box4. The E-boxes can be activated by the myogenic regulatory factors (MRFs: MyoD, Myf5, myogenin, and MRF4). MyoD upregulates MSTN transcription [33] and at the same time MSTN inhibits MyoD expression and activity regulating the differentiation of myoblasts into myotubes [34]. MyoD and MRF4 play competitive roles in myogenesis and might act as molecular switches to determine myogenic differentiation and cell proliferation, respectively [35]. Additional E-boxes were identified in the analysed region (such as an E-box located near the TATA2 in pig and an additional E-box in all mammalian but cattle) and in the distal region of the promoter of the other mammals (not included in Figure 3). In cattle, Spiller et al. [33] showed the importance of three functional E-boxes (E3, $\mathrm{E} 4$, and E6) of which the E6, occupied by MyoD in vitro and in vivo, resulted crucial for the MSTN promoter activity. The close position of functional E-boxes suggests that they might function as a cluster to better sustain the stability of DNAprotein. Across the MSTN promoter sequences of all considered livestock species we identified the conserved position of sites matching the consensus for FoxO binding and the adjacent SMAD box whose presence was not evidenced in previous works $[8,33,36]$. Recent data demonstrated that these factors appear to act through independent pathways but additively to regulate the expression of MSTN and 


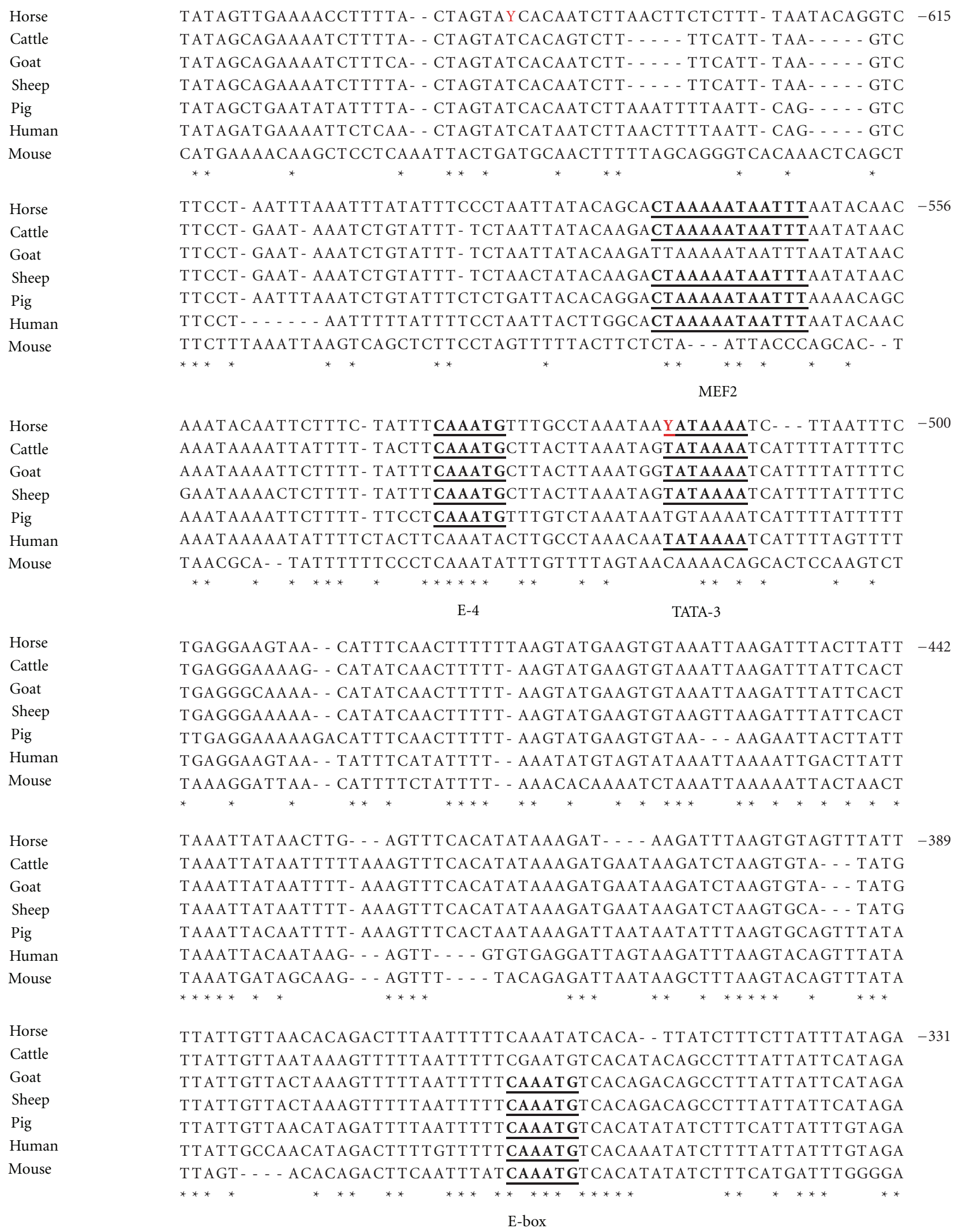

(a)

Figure 3: Continued. 


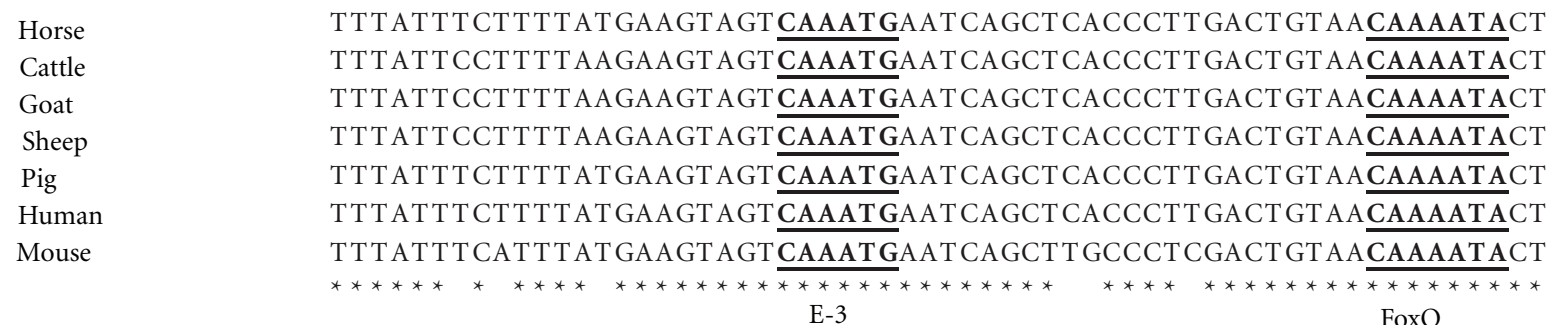

Horse

Cattle

Goat

Sheep

Pig

Human

Mouse

Horse

Cattle

Goat

Sheep

Pig

Human

Mouse

Horse

Cattle

Goat

Sheep

Pig

Human

Mouse

\begin{tabular}{|c|c|}
\hline Horse & TTAAAATTTTGCTTGGCATTGCTCAAAAGCAAAAGAAAA \\
\hline Cattle & TTAACGTTTGGCTTGGCGTTACTCAAAAGCAAAAGAAAA \\
\hline Goat & TTAACGTTTGGCTTGGCGTTACTCAAAAGCAAAAGAAA \\
\hline Sheep & TTAACGTTTGGCTTGGCGTTACTCAAAAGCAAAAGAAA \\
\hline Pig & TTAAAATTTTGCTTGGCGT TACTCAAAAGCA - - - - AA \\
\hline Human & TTAAAATTTTGCTTGGCATTACTCAAAAGCAAAAGAAA \\
\hline \multirow[t]{2}{*}{ Mouse } & CTAATATTTCACTTGGCATTACTCAAAAGCAA - - - A \\
\hline & $* * * \quad * * * \quad * * * * * * \quad * * \quad * * * * * * * * * * \quad * *$ \\
\hline Horse & - AAGGAAAAAGATTGAACTGATTTT-AAAATCATG +3 \\
\hline Cattle & - AAGGGAAAAGATTGTATTGATTTT - AAAACCATG \\
\hline Goat & - AAGGAAAAAGATTGTATTGA - - - - AAACCATG \\
\hline Sheep & TAAGGAAAAAGATTGTATTGATTTT - AAAACCATG \\
\hline Pig & - AAGGAGAAAGATTGTATTGATTTT - AAAATCATG \\
\hline Human & - AAGAAAAAAGATTATATTGATTTT - AAAATCATG \\
\hline \multirow[t]{2}{*}{ Mouse } & - AAAAAAAAAGATTGTGCT GATT TTTAAAATGATG \\
\hline & $* * * * * * *$ \\
\hline
\end{tabular}

(b)

GT T T GGT GACT T GT GACAGACAGGGT T TT AACCT CT GACAGCGAGAT T CATT GT GGAGCA GT T T GGT GACT T GT GA CAGACAGGGT T T T AACCT CT GACAGCGAGAT T CAT T GT GGAGCA

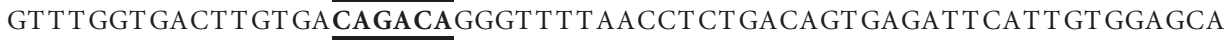

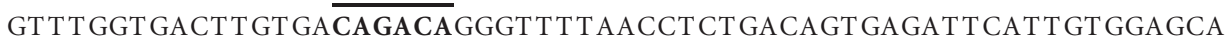
GTTT GGT GACT T GT GA CAGACA GGGT TTT AACCT CT GACAGCGAGATTCATT GT GGAGCA

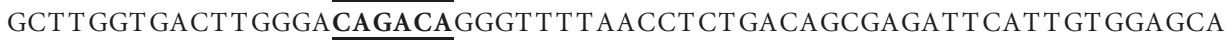

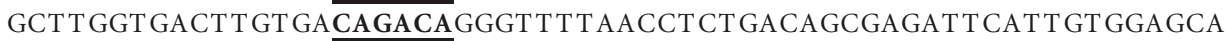
$* * * * * * * * * * * * * * * * * * * * * * * * * * * * * * * * * * * * * * * * * * * * * * * * * * * * * * * * *$ SMAD

GGAGCCAATCATAGATCCTGACGACACTTGTCTCATCAAAGTTGGAATATAAAAAGCCAC AGAG $\overline{\text { CCAAT }}$ CACAGATCCCGACGA $\overline{\text { CACTTGT CTCATCAAAGTTGGAATATAAAA }} \overline{\text { TAGCCAC }}$

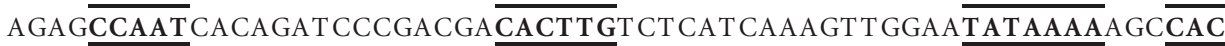

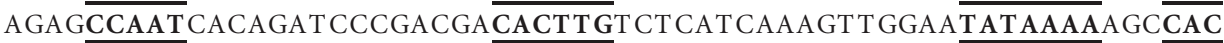

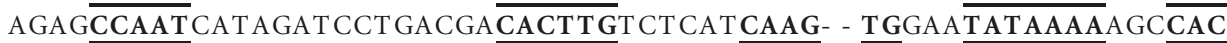

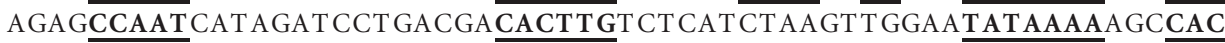

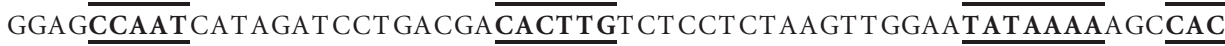

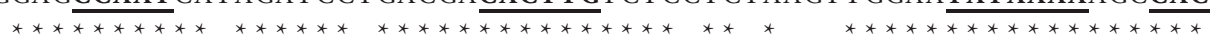
CCAAT E-2 E-box TATA-2

TTGGAATACAGTATAAAAGATTCACT GGT GT GGCAAGTT GT CT CT CAGACT GT ACAGGCA

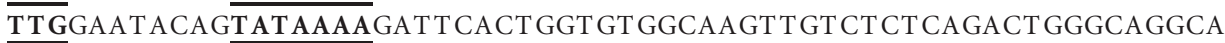

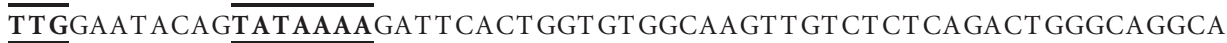
TTGGAAT ACAGTATAAAAGAT TCACT GGT GT GGCAAGT T GT CT CT CAGACT GGGCAGGCA TTGGAATACAGTATAAAAGAT TCACTGGTGT GGCAAGTTGTCTCTCAGACAGT GCAGGCA

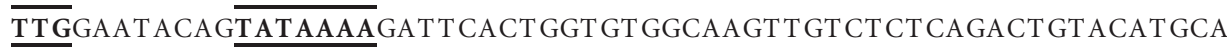
TTGGAATACAGTATACAGGACTCCCTGGCGTGGCAGGTTGTCTCTCGGACGGT ACATGCA $\not * * * * * * * * * * * * * * * * * * * * * * * * * * * * * * * * * * * * * * * * * * * * * * *$ E-1 TATA-1

TTAAAATTTTGCTTGGCATTGCTCAAAAGCAAAAGAAAAGTAAAAGGAAGAAATAAGAGC TTAACGTTTGGCT T GGCGTT ACTCAAAAGCAAAAGAAAAGTAAAAGGAAGAAGTAAGAAC TTAACGTTTGGCT T GGCGTT ACTCAAAAGCAAAAGAAAAGTAAAAGGAAGAAGTAAGAAC TTAACGTT T GGCTT GGCGT TACTCAAAAGCAAAAGAAAAGT AAAAGGAAGCAGTAAGAGC AAGTAAAAGGAAGAAACAAGAAC CTAATATTTCACTTGGCATTACTCAAAAGCAA - - - AAAGAAGAAATAAGAA- CAAGGG-
- AAGGGAAAAGATTGTATTGATTTT - AAAACCATG
- AAGGAAAAAGATTGTATTGA - . - - . AAACCATG
TAAGGAAAAAGATTGTATTGATTTT - AAAACCATG
$* * \quad * * * * * * \quad * * * \quad * * * * * *$

$-271$

FIgURE 3: Sequence analysis of the proximal promoter region and 5'-UTR of MSTN gene. Approximately 670 bp of the MSTN 5'-flanking region and $5^{\prime}$-UTR from horse, cattle, goat, human, mouse, pig, and sheep is shown. The consensus for transcription factor binding motives is shown in bold text and underlined. Numbering of the horse sequence is relative to the ATG start codon. Numbering of E-boxes is relative to the horse sequence. The two identified SNPs of horse MSTN gene are indicated with Y (T or C according to the IUPAC nomenclature) and in red. 
TABLE 3: Minor allele frequency (MAF) and haplotype (Hap*) frequencies of the two promoter SNPs of the MSTN gene in different horse breeds.

\begin{tabular}{|c|c|c|c|c|c|c|c|}
\hline Horse breeds & Types $\S$ & $\begin{array}{c}\text { Number of } \\
\text { horses }\end{array}$ & $\begin{array}{l}\text { MAF } \\
\text { g.26C }\end{array}$ & $\begin{array}{l}\text { MAF } \\
\text { g.156C }\end{array}$ & Hap [T:T] & Hap [T:C] & Hap [C:T] \\
\hline $\begin{array}{l}\text { Rapid Heavy } \\
\text { Draft }\end{array}$ & B & 81 & 0.12 & 0.15 & 0.73 & 0.15 & 0.12 \\
\hline Noric & B & 26 & 0.06 & 0.40 & 0.54 & 0.40 & 0.06 \\
\hline Bardigiano & M & 34 & - & 0.15 & 0.85 & 0.15 & - \\
\hline Haflinger & M & 31 & - & 0.37 & 0.63 & 0.37 & - \\
\hline Lipizzan & M & 12 & 0.21 & - & 0.79 & - & 0.21 \\
\hline Murgese & M & 12 & - & 0.17 & 0.83 & 0.17 & - \\
\hline Tolfetano & M & 7 & - & 0.29 & 0.71 & 0.29 & - \\
\hline $\begin{array}{l}\text { Uruguayan } \\
\text { Creole }\end{array}$ & M & 35 & - & 0.24 & 0.76 & 0.24 & - \\
\hline Italian Saddle & M-D & 30 & 0.05 & 0.10 & 0.85 & 0.10 & 0.05 \\
\hline Maremmano & M-D & 13 & - & 0.12 & 0.88 & 0.12 & - \\
\hline Quarter Horse & M-D & 15 & - & - & 1.00 & - & - \\
\hline Salernitano & M-D & 4 & - & 0.25 & - & - & - \\
\hline $\begin{array}{l}\text { Spanish } \\
\text { Purebred }\end{array}$ & M-D & 10 & - & - & 1.00 & - & - \\
\hline Ventasso & M-D & 8 & 0.12 & - & 0.88 & - & 0.12 \\
\hline Italian Trotter & $\mathrm{D}$ & 67 & 0.01 & - & 0.99 & - & 0.01 \\
\hline Thoroughbred & $\mathrm{D}$ & 11 & - & 0.05 & 0.95 & 0.05 & - \\
\hline
\end{tabular}

*Haplotypes for the g.26T $>\mathrm{C}$ and g.156T $>\mathrm{C}$ polymorphisms. ${ }^{\S}$ Types: $\mathrm{B}=$ brachimorphic or heavy, $\mathrm{M}=$ mesomorphic, $\mathrm{M}-\mathrm{D}=$ meso-dolichomorphic, $\mathrm{D}=$ dolichomorphic or light.

contribute to control muscle cell growth and differentiation $[37,38]$. In addition, FoxO transcription factors plays a critical role in development of muscle atrophy by stimulating proteolysis and by increasing myostatin expression. Putative E-boxes were identified both in intron 1 (six boxes) and in intron 2 (six boxes) and one putative E-box was located in the $3^{\prime}$-UTR at seven nucleotides downstream of the TGA stop codon (data not shown). The presence of E-boxes in the introns and $3^{\prime}$-UTR of equine MSTN gene has not been described yet even if their occurrence has been highlighted recently in introns of porcine MSTN gene [8].

3.2. Identification of Polymorphisms in the Horse MSTN Gene. Sequencing of the panel of horses of different morphological types revealed a total of seven single nucleotide polymorphisms (SNPs) (Figure 2). Two transitions were located in the promoter region at -646 (GQ183900:g.26T >C) and -516 (GQ183900:g.156T >C) bp upstream from the start codon. The g.26T $>$ C SNP was within a conserved position (except in mouse) but not within an identified known functional motif while the $\mathrm{g} .156 \mathrm{~T}>\mathrm{C}$ polymorphism was within a TATA box-like (TATA-3; YATAAA, Figure 3). Sequence alignments of the MSTN promoter regions of different species indicate that the g.26T and g.156T alleles derive from an ancestral MSTN sequence as most close species present the indicated nucleotides (Figure 3 and data not shown). The other five
SNPs were in intronic regions: four were localized in intron 1 and one in intron 2 (Figure 2). Three of the SNPs of intron 1 (g.1634T $>$ G, g.2115A $>$ G, and g.2327A $>C$ ) were also recently identified in Thoroughbred breeds [24]. One of which (g.2115A > G; indicated by [24] as g.66493737C>T) has been associated with sprinting ability and racing stamina in Thoroughbred horses [24]. The remaining SNPs were not reported by others and represent new polymorphisms of the horse MSTN gene. None of these intronic SNPs resided within splice sites or within particularly conserved sequence elements. No indels and synonymous or nonsynonymous substitutions were identified.

3.3. Analysis of Polymorphisms in Breeds with Different Morphological Types and Genetic Diversity Parameters. Allele frequencies for the two SNPs located in the promoter region (g.26T $>$ C and g.156T $>$ C) are shown in Table 3. The g.26T $>C$ SNP was polymorphic in 6 out of 16 breeds with higher observed frequency of the g.26C allele in the Lipizzan breed (0.21). For the g.156T $>C$ polymorphism, the mutant g.156C allele, which changes the predicted TATA box3-like, was detected in 11 out 16 breeds and was identified in homozygous condition in a few Bardigiano, Haflinger, Noric, Rapid Heavy Draft, and Uruguayan Creole horses.

Haplotype analyses of the two mutations showed the presence of three haplotypes: [g.26T:g.156T], [g.26T:g.156C], 
TABLE 4: Minor allele frequency (MAF), observed and expected heterozygosity (Het*), and haplotype (Hap ${ }^{\S}$ ) frequencies of the two promoter SNPs of the MSTN gene in horses with different morphological types.

\begin{tabular}{lcccccccc}
\hline Types $^{\#}$ & $\begin{array}{c}\text { Number of } \\
\text { horses }\end{array}$ & $\begin{array}{c}\text { MAF } \\
\text { g.26C }\end{array}$ & $\begin{array}{c}\text { MAF } \\
\text { g.156C }\end{array}$ & $\begin{array}{c}\text { Observed Het } \\
(\text { s.d. })^{\S}\end{array}$ & $\begin{array}{c}\text { Expected Het } \\
(\text { s.d. })^{\S}\end{array}$ & Hap [T:T] & Hap [T:C] & Hap [C:T] \\
\hline B & 107 & 0.11 & 0.21 & $0.24(0.09)$ & $0.26(0.10)$ & 0.69 & 0.22 & 0.09 \\
M & 131 & 0.02 & 0.22 & $0.18(0.20)$ & $0.19(0.22)$ & 0.76 & 0.22 & 0.02 \\
M-D & 80 & 0.04 & 0.07 & $0.11(0.03)$ & $0.11(0.03)$ & 0.89 & 0.08 & 0.03 \\
D & 78 & 0.01 & 0.01 & $0.02(0.01)$ & $0.02(0.01)$ & 0.98 & 0.01 \\
Total & 396 & 0.05 & 0.15 & $0.15(0.09)$ & $0.17(0.11)$ & 0.81 & 0.15 & 0.01 \\
\hline
\end{tabular}

* Means for the two loci and standard deviation, in parenthesis. ${ }^{\S}$ Haplotypes for the g.26T $>\mathrm{C}$ and g.156T $>\mathrm{C}$ polymorphisms. ${ }^{\#}$ Types: B= brachimorphic or heavy, $\mathrm{M}=$ mesomorphic, $\mathrm{M}-\mathrm{D}=$ meso-dolichomorphic, $\mathrm{D}=$ dolichomorphic or light.

and [g.26C:g.156T] (Table 3). The [T:T] haplotype could be the wild type according to its presence in all breeds and higher frequency (from 0.54 to 1.00 ). The [T:C] haplotype was observed in 10 breeds (frequency from 0.05 to 0.40 ), whereas the $[\mathrm{C}: \mathrm{T}]$ haplotype was identified only in 6 breeds (frequency from 0.01 to 0.21 ) (Table 3 ).

In order to evaluate if the two SNPs in the promoter region could account for a quote of variability related to morphological types, we classified the analysed horse breeds in four groups (brachymorphic, B; mesomorphic, M; mesodolichomorphic, M-D; and dolichomorphic, D) (see Materials and Methods). Several descriptive statistics summarizing the genetic diversity of these groups are reported in Table 4 . The $\mathrm{B}$ group showed the highest observed and expected heterozygosity $(0.24 \pm 0.09$ and $0.26 \pm 0.10$, respectively), whereas the $\mathrm{D}$ group had the lowest values $(0.02 \pm 0.01$ for both measures). For the g.26T $>$ C SNP, differences in allele frequencies were significant between $\mathrm{B}$ and the other three groups $(P<.0001$ for $\mathrm{B}$ versus $\mathrm{M}$ and $\mathrm{B}$ versus $\mathrm{D} ; P<$ .05 for $\mathrm{B}$ versus $\mathrm{M}-\mathrm{D})$. For the g.156T $>\mathrm{C}$ polymorphism, only the comparison between $\mathrm{B}$ and $\mathrm{M}$ groups was not significant. In particular, differences in allele frequencies were highly significant between the $\mathrm{B}$ and $\mathrm{D}$ groups and between the $\mathrm{M}$ and $\mathrm{D}$ groups $(P=3.78 \mathrm{E}-11$ and $P=$ $3.95 \mathrm{E}-9$, respectively. For the remaining comparisons: $P<.0001$ for $\mathrm{B}$ versus $\mathrm{M}-\mathrm{D}$ and for $\mathrm{M}$ versus $\mathrm{M}-\mathrm{D}$, $P<.01$ for M-D versus D). The overall $F_{\text {st }}$ value showed that the genetic differences among the groups accounted for $6.1 \%$ (3.6\% for the g.26T $>\mathrm{C}$ SNP and $7.0 \%$ for the g.156T $>$ C SNP) of the genetic variation. The AMOVA on haplotypes confirmed that a proportion of the total molecular variance was associated to morphological types of the horses. Using the four morphological types the molecular variance explained was $6.40 \%(P<.05)$. Grouping these four types into two groups $(B+M$ and $M-D+D)$ according to their similarities on morphological types the quote of explained molecular variance was $10.6 \%(P<.01)$. It could be possible that differences of allele and haplotype frequencies among types are influenced by phylogenetic closeness rather than any association with morphological types. This issue should be further investigated as, to our knowledge, there are no studies analyzing this question that include most of the breeds we investigated. However, Di Stasio et al. [39] analysed genetic relationships among only three breeds included in our study and evidenced significant genetic differentiation among Bardigiano, Haflinger, and Maremmano, suggesting that the results we obtained might not be biased by a putative common origin of the breeds. The association of the two promoter SNPs with morphological types could be due to linkage disequilibrium with alleles in other chromosome 18 loci that affect the variability of morphological traits in horses. However, based on our results it cannot be excluded that MSTN SNPs could influence morphological traits, that are indirectly related to muscle mass. A few SNPs in the promoter region of the swine MSTN gene were associated with muscularity, growth, and meat quality traits $[8,20,21]$. One of them, with high frequency in the muscled Belgian Pietrain breed, was associated with MSTN expression level, suggesting that promoter polymorphisms could contribute to muscle mass in this pig breed [8]. To demonstrate the putative functional role of the identified horse MSTN promoter SNPs, expression studies in skeletal muscle of animals with different genotypes should be performed. However, it is worth to point out that in vivo RNA expression studies in horses are very complicated as it is quite difficult to standardize temporary and permanent environmental factors (i.e. age, sex, management, feeding, etc.) that are major sources of variability in such experiments. For these reasons in vitro assays might be needed to clarify if the identified SNPs could alter MSTN gene expression. In addition association analysis in breeds segregating for the two promoter SNPs and for which estimated breeding values for several conformational and performance traits are available could be useful to further evaluate the association of these polymorphic sites with phenotypic traits.

\section{Acknowledgments}

The authors thank horse breeders, Italian Horse National Breeders Associations, Associazione Italiana Allevatori (A.I.A.), Istituto Sperimentale per la Zootecnia of Rome (Italy), and Association Rural de Uruguay for providing horse samples and genealogical information. They also thanks three anonymous reviewers for their comments that made it possible to improve the manuscript. This study was funded by the University of Bologna RFO. 


\section{References}

[1] A. C. McPherron, A. M. Lawler, and S.-J. Lee, "Regulation of skeletal muscle mass in mice by a new TGF- $\beta$ superfamily member," Nature, vol. 387, no. 6628, pp. 83-90, 1997.

[2] A. C. McPherron and S.-J. Lee, "Double muscling in cattle due to mutations in the myostatin gene," Proceedings of the National Academy of Sciences of the United States of America, vol. 94, no. 23, pp. 12457-12461, 1997.

[3] D. Joulia-Ekaza and G. Cabello, "Myostatin regulation of muscle development: molecular basis, natural mutations, physiopathological aspects," Experimental Cell Research, vol. 312, no. 13, pp. 2401-2414, 2006.

[4] N. F. Gonzalez-Cadavid, W. E. Taylor, K. Yarasheski et al., "Organization of the human myostatin gene and expression in healthy men and HIV-infected men with muscle wasting," Proceedings of the National Academy of Sciences of the United States of America, vol. 95, no. 25, pp. 14938-14943, 1998.

[5] A. Stratil and M. Kopecny, "Genomic organization, sequence and polymorphism of the porcine myostatin (GDF8; MSTN) gene," Animal Genetics, vol. 30, no. 6, pp. 468-469, 1999.

[6] F. Jeanplong, M. Sharma, W. G. Somers, J. J. Bass, and R. Kambadur, "Genomic organization and neonatal expression of the bovine myostatin gene," Molecular and Cellular Biochemistry, vol. 220, no. 1-2, pp. 31-37, 2001.

[7] R. Du, Y.-F. Chen, X.-R. An et al., "Cloning and sequence analysis of myostatin promoter in sheep," DNA Sequence, vol. 16, no. 6, pp. 412-417, 2005.

[8] A. Stinckens, T. Luyten, J. Bijttebier et al., "Characterization of the complete porcine MSTN gene and expression levels in pig breeds differing in muscularity," Animal Genetics, vol. 39, no. 6, pp. 586-596, 2008.

[9] M. Schuelke, K. R. Wagner, L. E. Stolz et al., "Myostatin mutation associated with gross muscle hypertrophy in a child," New England Journal of Medicine, vol. 350, no. 26, pp. 26822688, 2004.

[10] R. Kambadur, M. Sharma, T. P. L. Smith, and J. J. Bass, "Mutations in myostatin (GDF8) in double-muscled Belgian Blue and Piedmontese cattle," Genome Research, vol. 7, no. 9, pp. 910-916, 1997.

[11] L. Grobet, L. J. R. Martin, D. Poncelet et al., "A deletion in the bovine myostatin gene causes the double-muscled phenotype in cattle," Nature Genetics, vol. 17, no. 1, pp. 71-74, 1997.

[12] L. Grobet, D. Poncelet, L. J. Royo et al., "Molecular definition of an allelic series of mutations disrupting the myostatin function and causing double-muscling in cattle," Mammalian Genome, vol. 9, no. 3, pp. 210-213, 1998.

[13] C. Marchitelli, M. C. Savarese, A. Crisà, A. Nardone, P. A. Marsan, and A. Valentini, "Double muscling in Marchigiana beef breed is caused by a stop codon in the third exon of myostatin gene," Mammalian Genome, vol. 14, no. 6, pp. 392395, 2003.

[14] A. Clop, F. Marcq, H. Takeda et al., "A mutation creating a potential illegitimate microRNA target site in the myostatin gene affects muscularity in sheep," Nature Genetics, vol. 38, no. 7, pp. 813-818, 2006.

[15] I. A. Boman, G. Klemetsdal, T. Blichfeldt, O. Nafstad, and D. I. Våge, "A frameshift mutation in the coding region of the myostatin gene (MSTN) affects carcass conformation and fatness in Norwegian White Sheep (Ovis aries)," Animal Genetics, vol. 40, no. 4, pp. 418-422, 2009.
[16] I. A. Boman and D. I. Våge, "An insertion in the coding region of the myostatin (MSTN) gene affects carcass conformation and fatness in the Norwegian Spælsau (Ovis aries)," BMC Research Notes, vol. 2, article 98, 2009.

[17] D. S. Mosher, P. Quignon, C. D. Bustamante et al., "A mutation in the myostatin gene increases muscle mass and enhances racing performance in heterozygote dogs," PLoS Genetics, vol. 3, no. 5, pp. 779-786, 2007.

[18] R. H. S. Bellinge, D. A. Liberles, S. P. A. Iaschi, P. A. O’Brien, and G. K. Tay, "Myostatin and its implications on animal breeding: a review," Animal Genetics, vol. 36, no. 1, pp. 1-6, 2005.

[19] J. L. Gill, S. C. Bishop, C. McCorquodale, J. L. Williams, and P. Wiener, "Associations between the 11-bp deletion in the myostatin gene and carcass quality in Angus-sired cattle," Animal Genetics, vol. 40, no. 1, pp. 97-100, 2009.

[20] S. E. F. Guimaraes, C. H. Stahl, S. M. Lonergan, B. Geiger, and M. F. Rothschild, "Myostatin promoter analysis and expression pattern in pigs," Livestock Science, vol. 112, no. 1-2, pp. 143150, 2007.

[21] L. Yu, H. Tang, J. Wang et al., "Polymorphisms in the 5' regulatory region of myostatin gene are associated with early growth traits in Yorkshire pigs," Science in China C, vol. 50, no. 5, pp. 642-647, 2007.

[22] T. Hosoyama, S. Kawada, R. Oshiumi et al., "Molecular cloning of equine (thoroughbred) myostatin cDNA and detection of myostatin precursor proteins in the serum," Journal of Reproduction and Development, vol. 48, no. 4, pp. 335-342, 2002.

[23] A. R. Caetano, D. Pomp, J. D. Murray, and A. T. Bowling, "Comparative mapping of 18 equine type I genes assigned by somatic cell hybrid analysis," Mammalian Genome, vol. 10, no. 3, pp. 271-276, 1999.

[24] E. W. Hill, J. Gu, S. S. Eivers et al., "A sequence polymorphism in MSTN predicts sprinting ability and racing stamina in thoroughbred horses," PLoS ONE, vol. 5, no. 1, article e8645, 2010.

[25] A. T. Bowling and A. Ruvinsky, "Genetic aspect of domestication, breeds and their origins," in The Genetics of the Horse, A. T. Bowling and A. Ruvinsky, Eds., CAB International, Oxfordshire, UK, 2000.

[26] G. Aparicio, "Zootecnia especial. Etnologia compendiada," Deposito Legal, vol. 16, pp. 25-27, 1960.

[27] A. Falaschini, S. Rizzi, and M. Pasquini, "Morphological evolution of the Haflinger horse," Italian Journal of Animal Science, vol. 2, no. 1, pp. 595-597, 2003.

[28] A. Sabbioni, V. Beretti, A. Zanon et al., "Morphological evolution of Bardigiano horse," Italian Journal of Animal Science, vol. 4, no. 2, pp. 412-414, 2005.

[29] C. Dario, D. Carnicella, M. Dario, and G. Bufano, "Morphological evolution and heritability estimates for some biometric traits in the Murgese horse breed," Genetics and Molecular Research, vol. 5, no. 2, pp. 309-314, 2006.

[30] A. Falaschini and C. Gallinelli, "Morphological evolution of the Throroughbred reared in Italy," Annual Meeting of the Italian Society for Veterinary Sciences, vol. 60, pp. 497-498, 2006.

[31] F. C. Yeh, R. Yang, and T. Boyle, "POPGENE Version 1.31. Microsoft Windows-based freeware for population genetic analysis," 1999, http://www.ualberta.ca/ fyeh/.

[32] M. Stephens, N. J. Smith, and P. Donnelly, "A new statistical method for haplotype reconstruction from population data," American Journal of Human Genetics, vol. 68, no. 4, pp. 978$989,2001$. 
[33] M. P. Spiller, R. Kambadur, F. Jeanplong et al., "The myostatin gene is a downstream target gene of basic helix-loop-helix transcription factor MyoD," Molecular and Cellular Biology, vol. 22, no. 20, pp. 7066-7082, 2002.

[34] B. Langley, M. Thomas, A. Bishop, M. Sharma, S. Gilmour, and R. Kambadur, "Myostatin inhibits myoblast differentiation by down-regulating MyoD expression," Journal of Biological Chemistry, vol. 277, no. 51, pp. 49831-49840, 2002.

[35] X. Jin, J.-G. Kim, M.-J. Oh et al., "Opposite roles of MRF4 and MyoD in cell proliferation and myogenic differentiation," Biochemical and Biophysical Research Communications, vol. 364, no. 3, pp. 476-482, 2007.

[36] K. Ma, C. Mallidis, J. Artaza, W. Taylor, N. Gonzalez-Cadavid, and S. Bhasin, "Characterization of $5^{\prime}$-regulatory region of human myostatin gene: regulation by dexamethasone in vitro," American Journal of Physiology, vol. 281, no. 6, pp. E1128E1136, 2001.

[37] D. L. Allen and T. G. Unterman, "Regulation of myostatin expression and myoblast differentiation by FoxO and SMAD transcription factors," American Journal of Physiology, vol. 292, no. 1, pp. C188-C199, 2007.

[38] D. L. Allen and M. Du, "Comparative functional analysis of the cow and mouse myostatin genes reveals novel regulatory elements in their upstream promoter regions," Comparative Biochemistry and Physiology, vol. 150, no. 4, pp. 432-439, 2008.

[39] L. Di Stasio, G. Perrotta, M. Blasi, and C. Lisa, "Genetic characterization of the Bardigiano horse using microsatellite markers," Italian Journal of Animal Science, vol. 7, no. 2, pp. 243-250, 2008. 

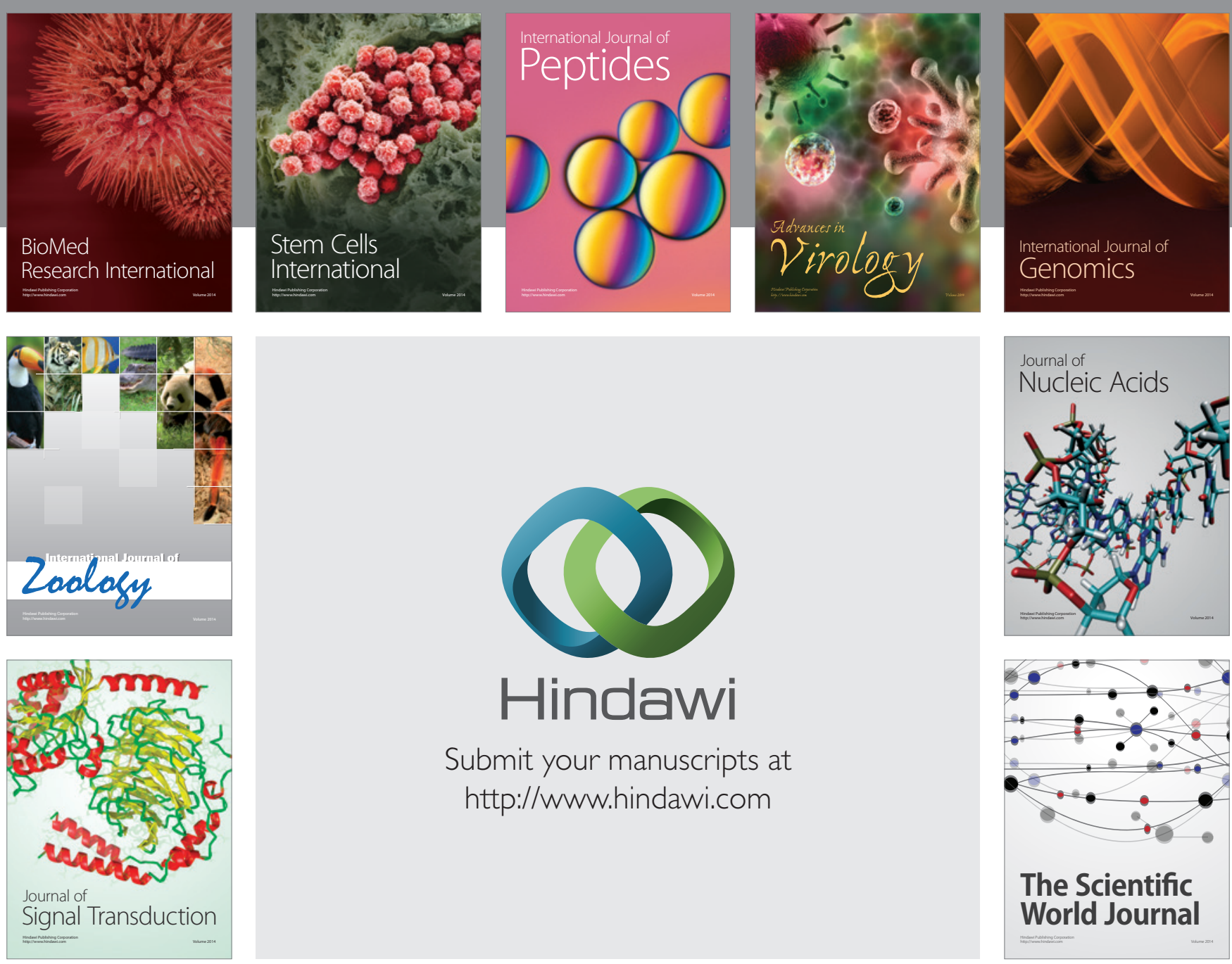

Submit your manuscripts at

http://www.hindawi.com
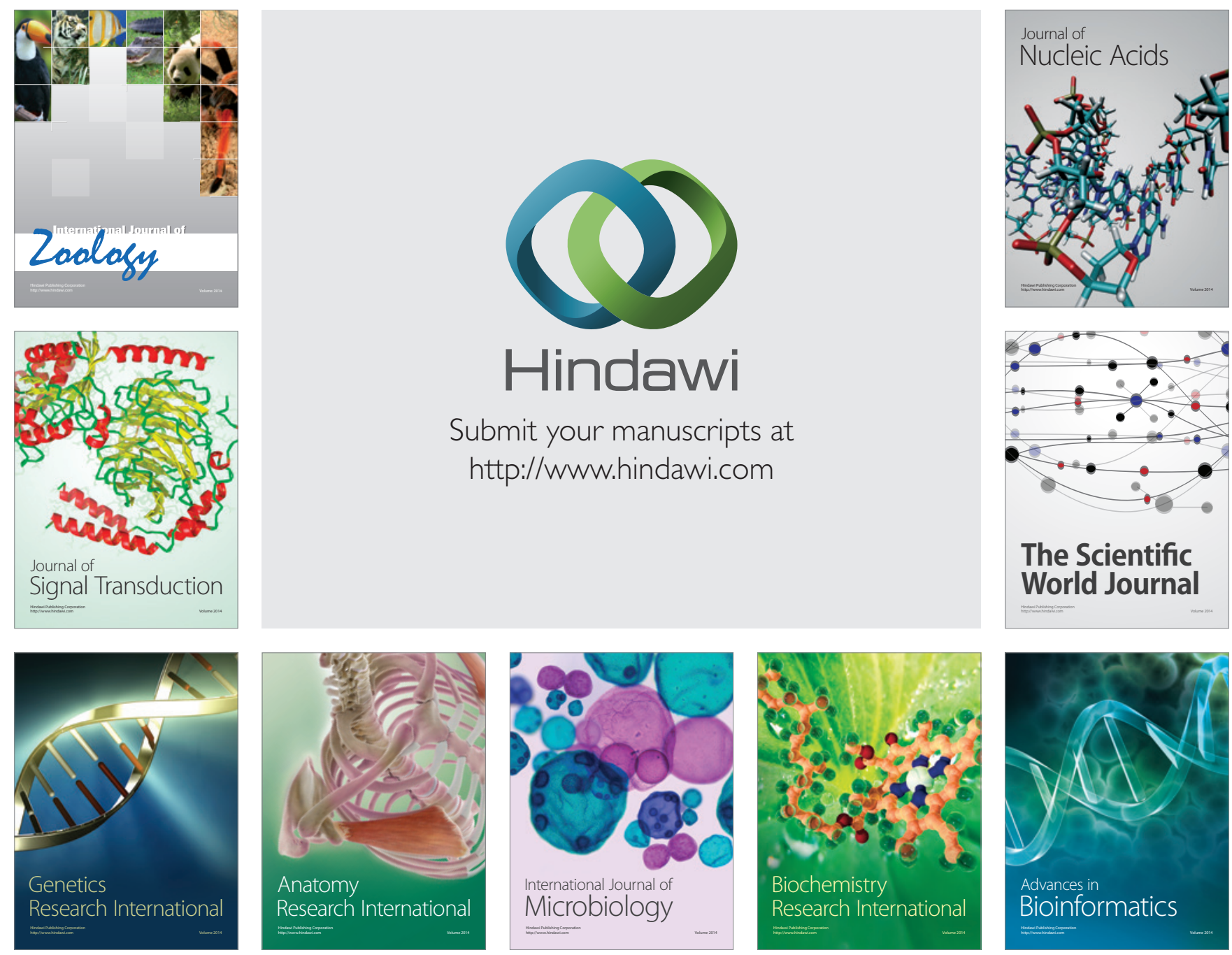

The Scientific World Journal
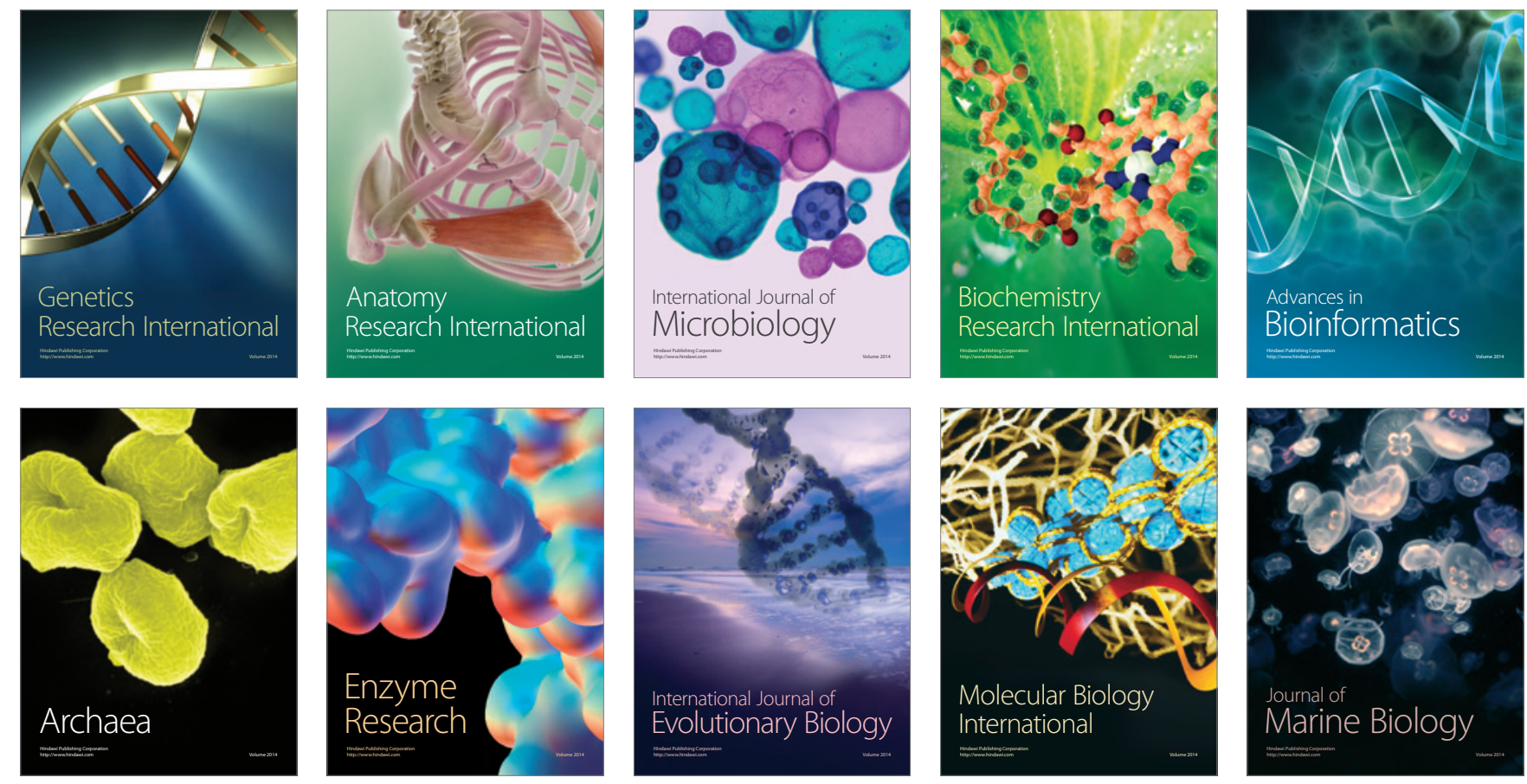